\title{
Influence of Ammonium Sulphate on Plant Growth in Nutrient Solutions and its Effect on Hydrogen-ion Concentration and Iron Availability. ${ }^{1}$
}

\author{
BY \\ LINUS H. JONES AND JOHN W. SHIVE. \\ With six Figures in the Text.
}

INTRODUCTION.

THE subject-matter reported in this paper is the result of a careful 1 investigation of the use of ammonium sulphate in a complete nutrient solution as a source of nitrogen for soy beans during the early stages of growth. In so far as possible particular attention has been given to the effect of ammonium sulphate on the growth of this plant, the effect on the solutions in contact with the plant roots, and the influence which this compound has on the availability to the plants of different forms of iron. A previous study with wheat (20) along similar lines has been carried out, though not so completely. The methods of solution culture followed were those of Tottingham (37) and Shive (36), and these need not be considered here except as found necessary to explain the methods and conditions under which the various experiments have been performed.

The ammonium sulphate was substituted for potassium nitrate in twenty representative solutions of the eighty-four comprising the Tottingham series, and run in parallel with the same solutions unmodified, all having a total osmotic concentration value of one atmosphere. At the end of each interval between two successive solution renewals the hydrogen-ion concentrations were determined, and it was found that during the early stages of growth the plant roots in contact with the solutions containing ammonium sulphate cause these solutions to become more acid in reaction; other solutions become less acid, as many investigators have previously reported.

Greater differences in plant growth are to be found with different forms of iron suppiied to the plants in these solutions than with any other factor.

${ }^{1}$ Paper No. I I 5 of the Journal Series, New Jersey Agricultural Experiment Station, Department of Plant Physiology. This paper will appear in Rutgers College Studies, vol. i.

[Annals of Botany, Vol. XXXVII. No. CXLVII. July, 1923.] 


\section{Fones and Shive.-Influence of Ammonium Sulphate}

Iron supplied in small quantities, 0.83 milligram per litre, in the form of ferric phosphate, does not appear to be available for the plants growing in the Tottingham solutions, but is sufficient to meet the requirements of the plants growing in the solutions containing ammonium sulphate. Ferrous sulphate, on the other hand, produces excellent growth in the Tottingham solutions, but when it is introduced into a solution containing ammonium sulphate it brings about a condition which is very toxic to plants. It was therefore necessary to work out the proper form and amounts of iron to be supplied to each series of cultures so that this element could not become a limiting factor for growth. As this was not done for each separate solution used, only general conclusions may be drawn. It must be emphasized that the results presented in this paper for soy beans may not wholly agree with those for wheat previously reported, since these are two very different types of indicator plants.

A review of the literature shows that the substitution of ammonium sulphate, either partially or wholly, for nitrate nitrogen is not a new procedure. Thus Lehmann (27) concluded that some plants require nitrate nitrogen for their normal development, others require ammonium nitrogen during the first half of their growth period and nitrate nitrogen during the last half of the life cycle.

Hutchinson and Miller $(17,18)$ obtained good growth with wheat and pea plants grown in a nutrient solution with ammonium sulphate as the source of nitrogen in such a way that nitrification could not occur, showing that the nitrogen was derived from the ammonium sulphate as ammonium and not as nitrate. They conclude that 'agricultural plants of various kinds can produce normal growth when supplied with nitrogen in the form of ammonium salts under conditions which exclude the possibility of nitrification'.

Other investigators interpret their data to the effect that the ammoniumion is directly absorbed by the plant, but the possibilities of nitrification were not entirely removed.

There is one crop which apparently requires the ammonium-ion, and this is rice. Kellner (23) found that rice in nutrient solutions did better in the early stages with its nitrogen supplied in the ammonium form. Later on nitrate is better, but it does best with a combination of the two forms of nitrogen. Nagaoka (29) recognized the superiority of ammonium salts over the nitrate forms for rice. Krauss $(25,26)$, Daikuhara (4), Kelley (21, 22), Trelease (39) with his co-workers Paulino (40) and Jurado (41) are other investigators who have found ammonium salts the best source of nitrogen for rice.

Wolkoff (43) has successfully used ammonium sulphate with nitrate in a four-salt solution, as have Espino (6) and Jones and Shive (20).

The following experiments were undertaken for the purpose of studying 
more closely and under controlled conditions the effect of the ammonium- . ion on the plants, on the reaction of the nutrient medium, and on the availability of other nutrient elements, especially that of iron.

\section{Methods of Procedure.}

The experimental work of this study was carried out with nutrient solutions as the culture media. Two series of solutions were used, each comprising twenty cultures. In the first series twenty representative solutions were chosen from the eighty-four of Tottingham's (37) complete series. The twenty solutions selected are uniformly distributed throughout the series, and are designated by the culture numbers referring to the positions which they occupy on the four-co-ordinate diagrammatic scheme employed by Tottingham. The second series was like the first in every respect, except that ammonium sulphate in equal osmotic concentrations was substituted for the potassium nitrate in the Tottingham solutions of the first series. Two control solutions serving as standards for comparison were added to each experiment. These consisted of Tottingham's best solution for wheat, number $T_{3} R_{1} C_{4}$ with a total osmotic concentration of 2.5 atmospheres, and Shive's (36) best solution for wheat, number $\mathrm{R}_{5} \mathrm{C}_{2}$ with a total osmotic concentration of $\mathrm{I} \cdot 75$ atmospheres. The latter contains no potassium nitrate. Thus any marked differences in the response of the plants towards the nutrient media in the corresponding cultures of the two series compared with the controls could be attributed to the influence of the ammonium sulphate upon the plants either directly or indirectly, assuming the cultures to be subjected alike to all other experimental conditions.

Baker's analysed salts were used to prepare the half-molecular stock solutions from which the culture solutions were made up. Table I gives the numbers of the cultures, which correspond to the numbers designating the solutions selected from the Tottingham series, and the partial volumemolecular concentrations of the salts as they occurred in the solutions of the two series to give a calculated total osmotic concentration value of one atmosphere. Cryoscopic determinations showed that this concentration was closely approximated in the solutions.

The essential element iron was supplied to all the cultures in equivalent amounts either in the form of the so-called insoluble ferric phosphate or the soluble ferrous sulphate. These two salts contain no anion different from those provided by the four main salts which are contained in each solution. These two sources of iron were used to determine which was the more efficient form of iron in the solutions of the two types. The ferric phosphate was supplied as a suspension in water from a stock supply prepared as described in a previous publication (19), and the ferrous sulphate was added in the form of a freshly prepared aqueous solution. The latter does not precipitate so rapidly nor so completely from the culture solutions here used 
as do other forms of soluble iron. By direct qualitative tests it was found that the iron added to the nutrient solutions in this soluble form was not all precipitated seven days after it had been added. The precipitation of this soluble iron is attended with a slight increase in the $\mathrm{H}$-ion concentration of the culture solution.

\begin{tabular}{|c|c|c|c|c|c|}
\hline \multirow{3}{*}{$\begin{array}{l}\text { Solution. } \\
\text { No. }\end{array}$} & \multicolumn{5}{|c|}{$\begin{array}{l}\text { Partial volume-molecular concentrations. }{ }^{1} \\
\text { Ammonium-sulphate series }(B) .\end{array}$} \\
\hline & \multicolumn{4}{|c|}{ Tottingham series $(A)$. } & \multirow[b]{2}{*}{$\left(\mathrm{NH}_{4}\right)_{2} \mathrm{SO}_{4}$} \\
\hline & $\mathrm{KNO}_{3}$ & $\mathrm{KH}_{2} \mathrm{PO}_{4}$. & $\mathrm{Ca}\left(\mathrm{NO}_{3}\right)_{2}$ & $\mathrm{MgSO}_{4}$ & \\
\hline $\mathrm{T}_{1} \mathrm{R}_{1} \mathrm{C}_{\mathrm{t}}$ & 0.0020 & 0.002 I I & $0.0014^{6}$ & 0.01659 & 0.0014 \\
\hline $\mathrm{C}_{3}$ & 0.0020 & 0.002 I I & $0.0043^{8}$ & 0.01185 & 0.0014 \\
\hline $\mathrm{C}_{5}$ & 0.0020 & 0.002 I I & 0.00730 & 0.007 I I & 0.0014 \\
\hline $\mathrm{C}_{7}$ & 0.0020 & 0.002 I I & 0.01022 & 0.00237 & 0.0014 \\
\hline $\mathrm{R}_{3} \mathrm{C}_{1}$ & 0.0060 & 0.002 I I & $0.001_{4} 6$ & ०.OI I 85 & $0.004^{2}$ \\
\hline $\mathrm{C}_{3}$ & 0.0060 & 0.002 I I & $0.0043^{8}$ & 0.007 I I & $0.004^{2}$ \\
\hline $\mathrm{C}_{5}$ & 0.0060 & 0.002 I I & 0.00730 & 0.00237 & $0.004^{2}$ \\
\hline $\mathrm{R}_{5} \mathrm{C}_{1}$ & 0.0100 & $0.002 \mathrm{II}$ & 0.00146 & 0.007 I I & 0.0070 \\
\hline $\mathrm{C}_{3}$ & 0.0100 & 0.002 I I & $0.0043^{8}$ & 0.00237 & 0.0070 \\
\hline $\mathrm{R}_{7} \mathrm{C}_{1}$ & 0.0140 & 0.002 I I & 0.00146 & 0.00237 & 0.0098 \\
\hline $\mathrm{T}_{3} \mathrm{R}_{1} \mathrm{C}_{1}$ & 0.0020 & 0.00633 & $0.0014^{6}$ & $0.0118_{5}$ & 0.0014 \\
\hline $\mathrm{C}_{3}$ & 0.0020 & 0.00633 & $0.0043^{8}$ & 0.007 I I & 0.0014 \\
\hline $\mathrm{C}_{5}$ & 0.0020 & 0.00633 & 0.00730 & 0.00237 & 0.0014 \\
\hline $\mathrm{R}_{3} \mathrm{C}_{1}{ }^{\circ}$ & 0.0060 & 0.00633 & $0.0014^{6}$ & 0.007 I I & $0.004^{2}$ \\
\hline $\mathrm{C}_{3}$ & 0.0060 & 0.00633 & $0.0043^{8}$ & 0.00237 & $0.004^{2}$ \\
\hline $\mathrm{R}_{5} \mathrm{C}_{1}$ & 0.0100 & 0.00633 & 0.00146 & 0.00237 & 0.0070 \\
\hline $\mathrm{T}_{5} \mathrm{R}_{1} \mathrm{C}_{1}$ & 0.0020 & 0.01055 & $0.0014^{6}$ & 0.007 II & 0.0014 \\
\hline $\mathrm{C}_{3}$ & 0.0020 & 0.01055 & $0.0043^{8}$ & 0.00237 & 0.0014 \\
\hline $\mathrm{R}_{3} \mathrm{C}_{1}$ & 0.0060 & 0.01055 & 0.00146 & 0.00237 & $0.004^{2}$ \\
\hline $\mathrm{T}_{7} \mathrm{R}_{1} \mathrm{C}_{1}$ & 0.0020 & 0.01477 & $0.0014^{6}$ & 0.00237 & $0.00 I_{4}$ \\
\hline
\end{tabular}

The Edna variety of soy bean, Soja max, was used throughout the different experiments. The seeds were germinated either in washed sand or sphagnum moss. When germinated in the sand it was necessary to incinerate the roots to obtain their dry weights, the loss of weight upon incineration being taken as the weight of the roots. Uniform seedlings were selected when the cotyledons were opened sufficiently to determine the presence and uniformity of the unopened plumule. Three seedlings were comprised in each culture and were mounted in the double-piece paraffined cork stoppers as devised by Tottingham. These were of proper size to fit the quart fruit jars of colourless glass which were used as solution containers. Manila paper cylindrical shells, black within and light on the outside like those described by Shive (36), were used to exclude light from the cultures and prevent heat absorption.

The solutions were renewed regularly at intervals of three and onehalf to four days. After each interval the solutions which had been used were tested for their hydrogen-ion concentrations. This was done by

1 Total osmotic concentration value of each solution, I atmosphere. 
means of the colorimetric method, using the indicators recommended by Clark and Lubs (2), the double-tube colour standards of Gillespie (10), and the apparatus devised by Van Alstine (42), and these concentrations were recorded in terms of $\mathrm{pH}$ values.

The plants were grown in the culture solutions during a period of five or six weeks. At the end of the growth periods of the different experiments the dry weights of the tops and roots were separately obtained by the usual method.

The non-solution environment was made uniform for all the cultures by employing the rotating table (36). Daily records were kept, in so far as this was possible, of the measurements characterizing the aerial conditions.

\section{EXPERIMENTAL RESUlts.}

The detailed results of the first two experiments are purposely omitted, as their inclusion would only be indicative of the more conclusive data that are here presented. The first of these experiments consisted in growing the plants for a five-week period in the various solutions of Table I, with iron supplied in the form of an aqueous suspension of ferric phosphate in the amount of 0.83 milligram of iron per litre of nutrient solution. In general appearance the plants of many of the cultures of the Tottingham series (series A) soon showed the chlorotic condition which is characteristic of plants suffering from lack of iron. The plants in the series containing ammonium sulphate (series B) did not present a chlorotic appearance. However, a yellow mottling was present later in both series, obscuring, if present, the chlorotic symptoms of lack of iron. The dry weights of the series containing ammonium sulphate were slightly superior to those of the Tottingham series, and the fact that the solutions containing ammonium sulphate grew more acid in contact with plant roots, while the Tottingham solutions grew less acid, suggests that this slight advantage of the series containing ammonium sulphate is due to the greater availability of the iron from the insoluble ferric phosphate in these solutions which have a tendency to become more acid.

In the second experiment the same amount of iron was supplied in the form of ferrous sulphate in a fresh aqueous solution. There was no chlorosis apparent in either series. About two weeks after the experiment was started many of the plants in both series exhibited a peculiar brown specking, especially on the unfolding new leaves. Later on this was succeeded by a general mottling of the leaves. That this was due to the ferrous sulphate was experimentally determined by setting up a supplementary experiment in which both ferrous sulphate and ferric phosphate were used as sources of iron. The specking and mottling persisted in the ferrous sulphate cultures, but were absent in those cultures receiving iron in the form of ferric phosphate. 
The dry weight yield values of this second experiment showed that the cultures of the Tottingham series (series A) were much superior to those of the series containing ammonium sulphate (series B). With the changing of one factor, that of the source of iron, a reversal of the superiority of the two types of solutions was brought about. When ferric phosphate is used as a source of iron, the solutions containing ammonium sulphate can make soluble enough iron from the amounts added to meet the requirements of the plants, but when ferrous sulphate is used in the solution containing ammonium sulphate it gives evidence of a toxic character not present in the Tottingham solutions.

Thus the indications are that the choice of a source of iron for plants in a nutrient solution must be very carefully made, with respect to the chemical composition of such a solution, in order to avoid iron toxicity and still supply sufficient available iron to prevent chlorosis in the plants.

Gris (11) in 1844 was the first to show the necessity of iron for the formation of chlorophyll in plants. The exact manner in which the plant utilizes iron, the most efficient form, and the proper amount to be supplied under a given set of experimental conditions, are yet to be determined. Tottingham and Beck (38) have shown that the response to iron during the early stages of growth by plants is dependent upon the amount of iron stored in the seed. Corson and Bakke (3), employing both ferrous and ferric forms of phosphate as sources of iron in nutrient solutions, found differences in their efficiency, and also differences in the response of different plants.

Jones and Shive (19) with Shive's three-salt solution $\mathrm{R}_{5} \mathrm{C}_{2}(36)$, and employing different increments of iron in the forms of ferrous sulphate and ferric phosphate, have shown that the insoluble ferric phosphate is not suitable for use with spring wheat in this culture solution. Ferrous sulphate, on the other hand, gave excellent results when supplied in quantities of 0.75 to 3.0 milligrams of iron per litre of nutrient solution. In a later publication (20) it was shown that in a solution containing ammonium sulphate the ferrous form of iron was quite toxic, and the ferric form sufficiently available to prevent chlorosis in the plants.

Gile and Carrero $(8,9)$, in solution cultures, have shown that the reaction, concentration of the solution, and amount of iron used have a marked influence upon the availability of iron for rice plants. Mazé (28), in a complete nutrient solution with ferrous sulphate (I00 milligrams per litre) as a source of iron, found that the presence of ammonium salts of 500 milligrams per litre produced a toxic condition for maize. Hartwell and Pember (13) found ferrous sulphate toxic to barley and rye seedlings in Knop's solution in quantities of five parts per million of iron or over, while Ruprecht (35) in another nutrient solution found ferrous sulphate to be toxic to clover seedlings with four parts per million.

To demonstrate more definitely the effect of these two forms of iron, 
ferric phosphate and ferrous sulphate, on the plants grown in the two types of solutions, varying amounts of iron in the two forms were used in an experiment comprising two series of twenty cultures each and two controls. Throughout each series the same solution was used for all the cultures, the cultures of each series differing only in the amounts of iron added. To represent one type Tottingham's solution $T_{1} R_{1} C_{5}$, as given in Table $I$, was chosen, and, as a representative of the other type, this solution was modified by substituting ammonium sulphate for the potassium nitrate as previously explained (solution $T_{1} R_{1} C_{5}$ of the ammonium sulphate series, Table $I$ ). The series in which the Tottingham solution was used will be designated series $\mathrm{C}$, and that in which the modified Tottingham solution was used will be designated series D. Ferric phosphate was supplied to half the cultures in each series in amounts varying from $0.01 \mathrm{mg}$. to $5.0 \mathrm{mg}$. of iron per litre of nutrient solution, and to the other half of the cultures in each series iron was supplied in corresponding amounts in the form of ferrous sulphate, but no iron was added to the controls. The culture methods pursued throughout were precisely the same as those previously described. The cultures were conducted during a growth period of thirty-five days.

In the cultures of the Tottingham series $\mathrm{C}$ containing iron in the form of ferric phosphate a chlorotic condition appeared within five days after the experiment was started. In this series at harvest time those cultures receiving one milligram of iron or more had recovered. The cultures of the ammonium-sulphate series D receiving the same form of iron (ferric phosphate) were all green and healthy except the one culture receiving the smallest amount of iron (0.0I mg.), which was slightly chlorotic.

In the cultures supplied with ferrous sulphate, specking of the leaves became apparent within ten days, appearing in the Tottingham series $C$ in cultures receiving 0.75 milligram of iron or more, and in the ammoniumsulphate series D in cultures receiving $0 \cdot 10$ milligram of iron or more. No specking was observed in cultures grown in solutions supplied with ferric phosphate. At the time of harvest the plants in the Tottingham solutions supplied with ferrous sulphate were healthy and in a vigorous condition, but in the solutions containing ammonium sulphate supplied with ferrous sulphate as the source of iron, the plants presented a very poor appearance, with yellow, dying, or dead leaves, and this sickly appearance increased in intensity with increase of iron above 0.25 milligram per litre of solution.

At the end of the growth period of thirty-five days the dry weights of the tops and roots were obtained in the usual way. The yields of the cultures of the two series, together with the averages of the hydrogen-ion concentrations in terms of $\mathrm{pH}$ values of the solutions obtained at the end of the various growth intervals, are given in Table II. The yield values of tops and roots from the cultures supplied with ferric phosphate as the source of iron are represented graphically in Fig. I, the upper set of graphs 
representing the yields of tops and the lower set the root yields. The dryweight values as ordinates are here plotted against the amounts of iron in milligrams per litre of solution as abscissas.

\section{TABLE II.}

Hydrogen-ion concentrations and dry-weight yields of soy bean tops and roots grown in two types of mutrient solutions supplied with varying amounts of iron in the form of ferric phosphate and ferrous sulphate.

\begin{tabular}{|c|c|c|c|c|c|c|c|}
\hline \multirow{3}{*}{$\begin{array}{l}\text { Source } \\
\text { of } \\
\text { iron. }\end{array}$} & \multirow{3}{*}{$\begin{array}{l}\text { Amounts } \\
\text { of iron } \\
\text { mg. per } \\
\text { litre. }\end{array}$} & \multicolumn{3}{|c|}{$\begin{array}{l}\text { Series } C \text {. } \\
\text { (Tottingham solution } T_{1} R_{1} C_{5} \text { ) }\end{array}$} & \multicolumn{3}{|c|}{$\begin{array}{l}\text { (Modified Tottingham solution } \\
\left.\qquad T_{1} R_{1} C_{5}\right) .\end{array}$} \\
\hline & & \multicolumn{2}{|c|}{ Dry weights. } & \multirow{2}{*}{$\begin{array}{l}H \text {-ion } \\
\text { concen- } \\
\text { trations. }\end{array}$} & \multicolumn{2}{|c|}{ Dry weights. } & \multirow{2}{*}{$\begin{array}{l}H \text {-ion } \\
\text { concen- } \\
\text { trations. }\end{array}$} \\
\hline & & Tops. & Rnots. & & Tops. & Roots. & \\
\hline \multirow{12}{*}{$\mathrm{FePO}_{4}$} & Mg. & Grm. & Grm. & $\mathrm{pH}^{1}$ & Grm. & Grm. & $\mathrm{pH}$ \\
\hline & 0.00 & I. 6053 & 0.2795 & $5 \cdot 75$ & $3 \cdot 7769$ & $0.49^{20}$ & $4 \cdot 53$ \\
\hline & $0.0 \mathrm{I}$ & $1 \cdot 7109$ & $0.356 \mathrm{I}$ & 5.80 & 4.2117 & 0.5428 & $4 \cdot 53$ \\
\hline & 0.10 & 2.4170 & 0.4715 & 5.87 & $4 \cdot 5662$ & 0.6320 & $4 \cdot+4$ \\
\hline & 0.25 & 2.2737 & 0.3734 & 5.89 & $4 \cdot 390 \mathrm{I}$ & 0.7113 & $4 \cdot 64$ \\
\hline & 0.50 & $2 \cdot 6455$ & 0.4768 & 5.94 & $4.37 \mathrm{I}_{5}$ & 0.7157 & 4.67 \\
\hline & 0.75 & 2.6365 & 0.4188 & $5 \cdot 9^{5}$ & 4.0922 & 0.7309 & 4.67 \\
\hline & I.00 & $3.594^{2}$ & $0.6 \mathrm{IOI}$ & 6.03 & 4.4 I93 & 0.6973 & $4 \cdot 73$ \\
\hline & $I \cdot 50$ & 4.0236 & $0.69^{6} 3$ & 6.09 & 4.2285 & $0.7 \mathrm{I} 57$ & 4.62 \\
\hline & 2.00 & $4 \cdot 3687$ & 0.7880 & $6 \cdot 13$ & $4 \cdot 57^{89}$ & $0.704 \mathrm{I}$ & $4 \cdot 75$ \\
\hline & 3.00 & $4 \cdot 345^{8}$ & 0.6555 & $6 \cdot 19$ & $4.472 \mathrm{I}$ & 0.7079 & $4 \cdot 59$ \\
\hline & 5.00 & $3 \cdot 79^{6} 5$ & 0.66 I I & 6.03 & $4^{-1} 79^{6}$ & 0.6328 & 4.63 \\
\hline \multirow{11}{*}{$\mathrm{FeSO}_{4}$} & 0.00 & I. 6053 & 0.2795 & $5 \cdot 75$ & $3 \cdot 7769$ & 0.4920 & 4.53 \\
\hline & 0.01 & $2 \cdot 2793$ & 0.4510 & 5.85 & 4.6748 & 0.7386 & 4.53 \\
\hline & 0.10 & $4 \cdot 14^{6} \mathrm{I}$ & $0.75^{17}$ & 6.24 & 4.9910 & 0.6485 & $4 \cdot 49$ \\
\hline & 0.25 & $4 \cdot 3252$ & 0.7253 & 6.23 & 3.9627 & $0.44^{29}$ & $4 \cdot 49$ \\
\hline & $0.5^{0}$ & 4.2039 & 0.6045 & $6 \cdot 20$ & 3.1440 & 0.3168 & 4.50 \\
\hline & 0.75 & $3.474 \mathrm{I}$ & $0.494^{2}$ & $6 .{ }^{2} 5$ & $2 \cdot 7560$ & $0.3^{6} \mathrm{I} 9$ & $4 \cdot 5^{6}$ \\
\hline & 1.00 & $3.935^{8}$ & 0.5178 & $6 \cdot 14$ & $2.8_{5} \mathrm{I}_{3} 3$ & $0.34^{8} 5$ & $4 \cdot 57$ \\
\hline & 1.50 & 3.9546 & $0.54^{8} 7$ & 6.13 & $2 \cdot 1728$ & 0.2753 & $4 \cdot 57$ \\
\hline & 2.00 & 3.7229 & 0.4334 & 6.08 & $2 \cdot 143^{2}$ & 0.2725 & $4 \cdot 54$ \\
\hline & 3.00 & 3.6916 & 0.4878 & 6.07 & I. 8180 & $0.244^{1} 7$ & $4.5^{8}$ \\
\hline & 5.00 & $3 \cdot 3^{2} 45$ & 0.4025 & $6.0 \mathrm{I}$ & $1.962 \mathrm{I}$ & $0.3^{\mathrm{I}} 49$ & 4.57 \\
\hline
\end{tabular}

As indicated by the graphs of Fig. I the varying amounts of iron in the form of ferric phosphate have a very great influence on the increase of the dry-weight values of the tops and roots in the Tottingham series C. The graphs strikingly show that a maximum growth can be obtained in the ammonium-sulphate series D with a very small amount of iron in this form, and that increasing the amount does not increase the yield. In the case of the Tottingham series $C$ the yields of the cultures do not begin to approach the yields of the ammonium-sulphate series D until 2 milligrams or more of iron are employed. From the results of this experiment it may be stated in general that the presence of ammonium sulphate in a solution, either through its influence on the hydrogen-ion concentration or the possible

1 These values represent the averages of all the determinations made for each solution at the end of the growth intervals throughout the experiment period. The initial $\mathrm{pH}$ value of all the solntions in each series was approximately $4 \cdot 8$. 
effect it may have on permeability, makes the iron phosphate so available that the iron requirements of the plants are satisfied with a very small amount of iron in this form. With the Tottingham solutions greater amounts of the ferric phosphate must be added to the solutions to obtain maximum yields. The fact must not be overlooked, however, that different indicator plants may have different iron requirements, that a growth period of thirty-five days is required to bring soy bean plants to the flowering stage, and that during the reproductive and the later growth phases the iron requirements

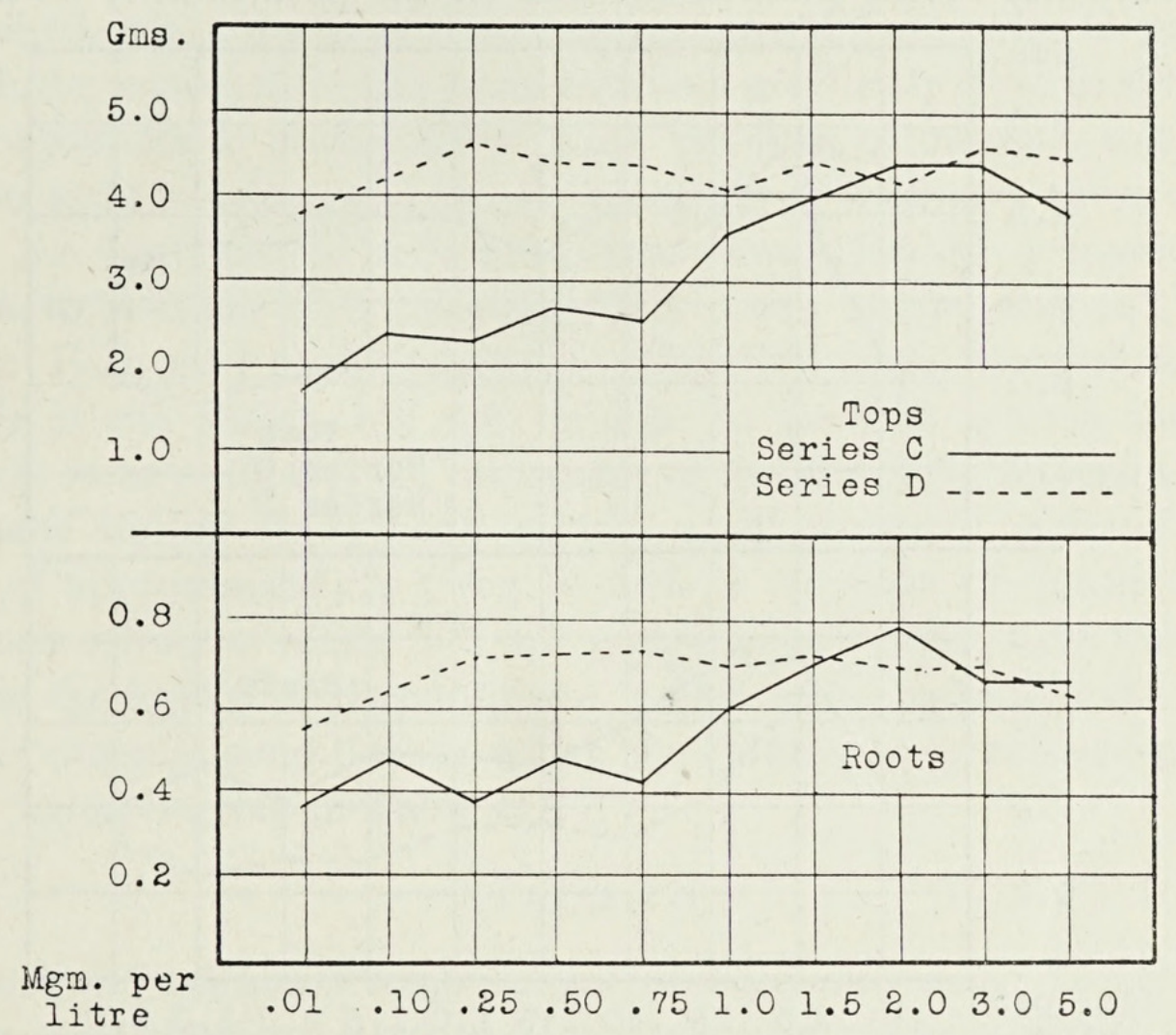

FIG. I. Graphs of actual yield values of soy bean tops and roots grown in Tottingham's solution $\mathrm{T}_{1} \mathrm{R}_{1} \mathrm{C}_{5}$ (series $\mathrm{C}$ ), and in the ammonium-sulphate modification of this solution (series $\mathrm{D}$ ), supplied with varying amounts of iron in the form of ferric phosphate.

of these plants may be entirely different from the demands during the vegetative phases of growth.

The dry-weight yield values from the cultures supplied with ferrous sulphate, as given in Table II, are graphically represented in Fig. 2. It will be observed from this figure and from the data of Table III that ferrous sulphate has a very depressing effect upon the dry weight yields of both tops and roots in the ammonium-sulphate series $\mathrm{D}$. That this is a toxic effect is very evident from the general appearance of the plants, and from the fact that the yields are very much lower than the control in which no iron was supplied. On the other hand, the soluble ferrous sulphate is a very good source of iron for the plants in the solutions of the Tottingham series C, even in very small amounts.

The toxicity which occurs with plants grown in solutions containing 
ammonium sulphate when supplied with iron in the form of ferrous sulphate, may be indirectly related to the $\mathrm{H}$-ion concentration of the solutions. As has been shown, the $\mathrm{H}$-ion concentration. of the solutions containing ammonium sulphate is usually increased and maintained at a relatively high level during contact with the roots of growing plants, while the $\mathrm{H}$-ion concentration of the Tottingham solutions under similar conditions is rapidly decreased. Thus the solubility and therefore the availability of iron is high in the former and relatively low in the latter. This, together with the possible influence of the ammonium salt on the permeability of the plant

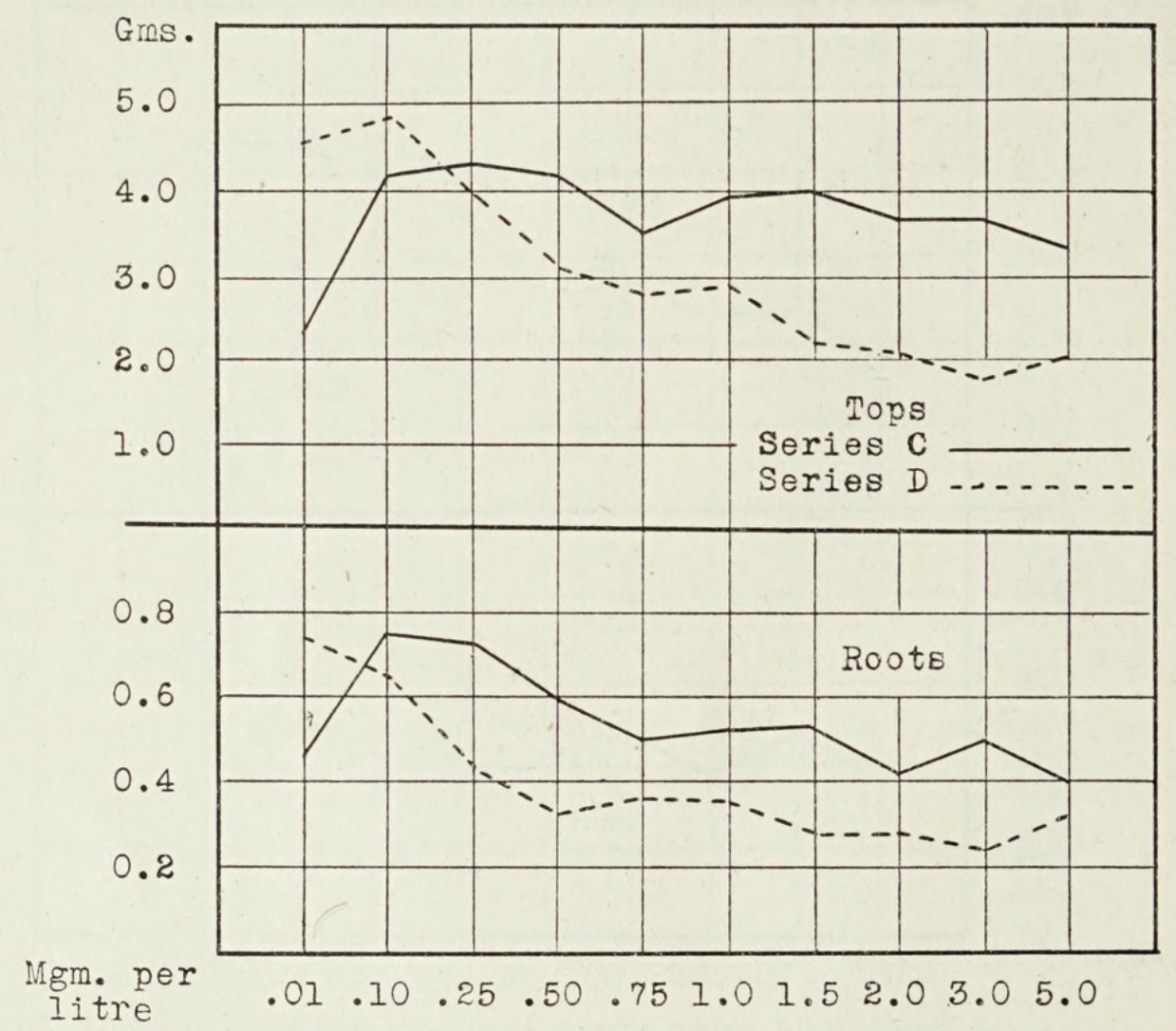

FIG. 2. Graphs of actual yield values of soy bean tops and roots grown in Tottingham's solution $T_{1} R_{1} C_{5}$ (series $C$ ), and in the ammonium-sulphate modification of this solution (series $D$ ), supplied with the varying amounts of iron in the form of ferrous sulphate.

cells for iron, may readily account for the difference in the behaviour of the plants towards iron in the two types of solutions, and for the toxic effects produced when ferrous sulphate in any but exceedingly low concentrations is used as the source of iron for plants in solutions containing ammonium sulphate.

From a consideration of the data presented in the above experiments it is evident that the form and quantity of iron in a medium for plant growth is a very important factor to be considered in connexion with the growth of plants in solution cultures.

Influence of Salt Proportions on the Yields of Tops and Roots.

This experiment was carried out for the purpose of determining the effect of salt proportions on the growth of soy bean plants in the Tottingham 
solutions, and in the modified Tottingham solutions as described in Table I, when supplied with suitable forms of inorganic iron in concentrations which were found in the preceding experiments to be approximately optimal for the growth of these plants. Three series of cultures were conducted simultaneously. The nutrient media used with two of these series, which will be designated series $\mathrm{E}$ and series $\mathrm{F}$, consisted of the Tottingham solutions (Table I) supplied with iron in the form of ferric phosphate and ferrous sulphate, respectively, corresponding solutions of the two series being alike in every respect except in the form and amounts of iron used. The third series, which will be designated the ammonium-sulphate series $\mathrm{G}$, was carried out with the modified Tottingham solutions previously described (Table I) Ferric phosphate in quantities of $2 \mathrm{mg}$. per litre of nutrient solution was added to each solution of series $E$ and series $G$ whenever these were pre pared. At the time of each solution renewal, freshly prepared ferrous sulphate in solution form was added to each of the nutrient solutions of series $\mathrm{F}$ in very small quantities, sufficiently large, however, to prevent chlorosis in the plants, but not enough to produce serious specking of the leaves in any culture. In the course of the nine solution renewals which were made during the growth period, each culture of series $F$ received a total of approximately $2.5 \mathrm{mg}$. of iron in the form of ferrous sulphate, while each culture of series $\mathrm{E}$ and $\mathrm{F}$ received during the same time $\mathrm{I} 8 \mathrm{mg}$. of iron in the form of ferric phosphate. The record indicating the nature of the environmental conditions to which the cultures were exposed during the growth period is given in Table III.

\section{TABLE III.}

Maximum and minimum temperatures, average daily water loss by evaporation from standard white and black spherical atmometers, and character of days for the experimental period.

\begin{tabular}{|c|c|c|c|c|c|c|c|c|c|c|c|c|}
\hline \multicolumn{2}{|c|}{$\begin{array}{l}\text { Experimental period } \\
\text { I } 92 \mathrm{I} .\end{array}$} & \multicolumn{2}{|c|}{$\begin{array}{l}\text { Air tem- } \\
\text { perature. }\end{array}$} & \multicolumn{3}{|c|}{$\begin{array}{l}\text { Average daily } \\
\text { evaporation. }{ }^{1}\end{array}$} & \multicolumn{3}{|c|}{$\begin{array}{l}\text { Radio- } \\
\text { evaporation. }\end{array}$} & \multicolumn{3}{|c|}{ Number of days. } \\
\hline 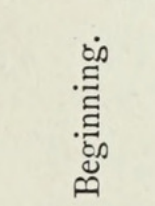 & $\begin{array}{l}\dot{0} \\
\dot{\Xi} \\
\text { : }\end{array}$ & 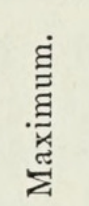 & 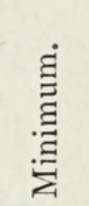 & 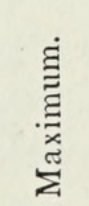 & 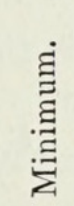 & 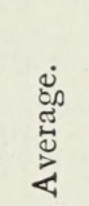 & 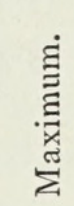 & 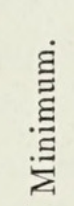 & 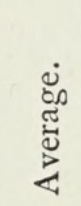 & 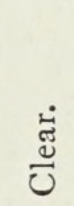 & 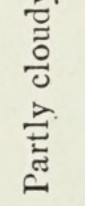 & $\begin{array}{l}\dot{\vec{c}} \\
\frac{\overrightarrow{0}}{0}\end{array}$ \\
\hline July 24 & Aug. 29 & $\begin{array}{l}{ }^{\circ} \mathrm{C} . \\
4^{2} \cdot 0\end{array}$ & $\begin{array}{l}{ }^{\circ} \mathrm{C} . \\
{ }_{\mathrm{I}} 3 \cdot 5\end{array}$ & $\begin{array}{l}\text { c.c. } \\
26 \cdot I\end{array}$ & $\begin{array}{l}\text { c.c. } \\
2 \cdot 2\end{array}$ & $\begin{array}{l}\text { c.c. } \\
16.0\end{array}$ & $\begin{array}{l}\text { c.c. } \\
6.1\end{array}$ & $\begin{array}{l}\text { c.c. } \\
0.2\end{array}$ & $\begin{array}{l}\text { c.c. } \\
3.6\end{array}$ & 22 & 9 & 5 \\
\hline
\end{tabular}

In general, all the cultures appeared quite healthy on the harvest date.

1 Evaporation was measured by means of the Livingston standard spherical atmometers. Livingston, B. E. : Atmometry and the Porous Cup Atmometer. Plant World, I8, $2 \mathrm{I}-30,5 \mathrm{I}-74$, 95-III, I43-49, I9I5. Reprinted, Tucson, I9I5.

2 The values given for radio-evaporation represent the average daily excess of water loss from the standard black spherical atmometer over that from the white. 
Slight specking occurred on the leaves of the plants in some of the Tottingham cultures of series $\mathrm{F}$ supplied with ferrous sulphate, but this was not at all serious, and after two weeks from the time the cultures were started it did not increase appreciably.

The hydrogen-ion concentrations of the culture solutions were determined at the end of each growth interval between two successive solution renewals. In Table IV are given the initial $\mathrm{pH}$ values of the culture solutions, the highest and lowest values obtained during the growth periods, and the average of all the values for each solution of the three series.

\section{TABLE IV.}

$\mathrm{pH}$ values of the culture solutions of the Tottingham series ( $E$ and $F)$ and the ammonium-sulphate series $(G)$ supplied with iron in the proper form and in sufficient amounts to prevent chlorosis.

Tottingham series $(E)$. Source of iron $\mathrm{FePO}_{4}$.

Tottingham series $(F)$. Source of iron $\mathrm{FeSO}_{4}$.

\begin{tabular}{|c|c|c|c|c|c|c|c|c|c|c|c|c|}
\hline \multirow{2}{*}{$\begin{array}{l}\text { Culture } \\
\text { No. }\end{array}$} & \multicolumn{4}{|c|}{$\mathrm{pH}$ values. } & \multicolumn{4}{|c|}{$\mathrm{pH}$ values. } & \multicolumn{4}{|c|}{$\mathrm{pH}$ values. } \\
\hline & $\begin{array}{l}\text { Ini- } \\
\text { tial. }\end{array}$ & $\begin{array}{l}\text { High- } \\
\text { est. }\end{array}$ & $\begin{array}{l}\text { Low- } \\
\text { est. }\end{array}$ & $\begin{array}{l}\text { Aver. } \\
\text { age. }\end{array}$ & $\begin{array}{l}\text { Ini- } \\
\text { tial. }\end{array}$ & $\begin{array}{l}\text { High- } \\
\text { est. }\end{array}$ & $\begin{array}{l}\text { Low- } \\
\text { est. }\end{array}$ & $\begin{array}{l}\text { Aver- } \\
\text { age. }\end{array}$ & $\begin{array}{l}\text { Ini- } \\
\text { tial. }\end{array}$ & $\begin{array}{c}\text { High- } \\
\text { est. }\end{array}$ & $\begin{array}{l}\text { Lorv- } \\
\text { est. }\end{array}$ & $\begin{array}{c}\text { Aver } \\
\text { age. }\end{array}$ \\
\hline $\begin{array}{r}{ }_{1} \mathrm{R}_{1} \mathrm{C}_{1} \\
\mathrm{C}_{3} \\
\mathrm{C}_{5} \\
\mathrm{C}_{7} \\
\mathrm{R}_{3} \mathrm{C}_{1} \\
\mathrm{C}_{3} \\
\mathrm{C}_{5} \\
\mathrm{R}_{5} \mathrm{C}_{1} \\
\mathrm{C}_{3} \\
\mathrm{R}_{7} \mathrm{C}_{1}\end{array}$ & 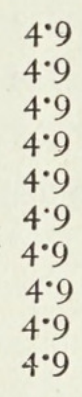 & $\begin{array}{l}6 \cdot 2 \\
6 \cdot 6 \\
6 \cdot 6 \\
6 \cdot 2 \\
6 \cdot 2 \\
6 \cdot 6 \\
6 \cdot 1 \\
6 \cdot 2 \\
6 \cdot 2 \\
6 \cdot 2\end{array}$ & $\begin{array}{l}5 \cdot 1 \\
5 \cdot 2 \\
5 \cdot 2 \\
5 \cdot 3 \\
5 \cdot 3 \\
5 \cdot 3 \\
5 \cdot 3 \\
5 \cdot 2 \\
5 \cdot 3 \\
5 \cdot 3\end{array}$ & $\begin{array}{l}5 \cdot 75 \\
5 \cdot 96 \\
6 \cdot 02 \\
5 \cdot 75 \\
5 \cdot 86 \\
5 \cdot 99 \\
5 \cdot 78 \\
5 \cdot 85 \\
5 \cdot 83 \\
5 \cdot 80\end{array}$ & $\begin{array}{l}4 \cdot 9 \\
4 \cdot 9 \\
4 \cdot 9 \\
4 \cdot 9 \\
4 \cdot 9 \\
4 \cdot 9 \\
4^{*} 9 \\
4 \cdot 9 \\
4 \cdot 9 \\
4 \cdot 9\end{array}$ & $\begin{array}{l}6 \cdot 4 \\
6 \cdot 6 \\
6 \cdot 6 \\
6 \cdot 3 \\
6 \cdot 4 \\
6 \cdot 4 \\
6 \cdot 4 \\
6 \cdot 5 \\
6 \cdot 5 \\
6 \cdot 4\end{array}$ & $\begin{array}{l}5 \cdot I \\
5 \cdot 2 \\
5 \cdot 3 \\
5 \cdot 3 \\
5 \cdot 1 \\
5 \cdot 2 \\
5 \cdot 3 \\
5 \cdot 3 \\
5 \cdot 3 \\
5 \cdot 3\end{array}$ & $\begin{array}{l}5 \cdot 84 \\
5 \cdot 99 \\
6 \cdot 21 \\
6 \cdot 01 \\
5 \cdot 79 \\
6 \cdot 05 \\
6 \cdot 06 \\
5 \cdot 88 \\
6 \cdot 08 \\
5 \cdot 88\end{array}$ & $\begin{array}{l}4 \cdot 9 \\
4 \cdot 9 \\
4^{\circ} \cdot 9 \\
4 \cdot 9 \\
4 \cdot 9 \\
4 \cdot 9 \\
4 \cdot 9 \\
4 \cdot 9 \\
4 \cdot 9 \\
4 \cdot 9\end{array}$ & $\begin{array}{l}6 \cdot 0 \\
5 \cdot 5 \\
5 \cdot 0 \\
4 \cdot 7 \\
5 \cdot 3 \\
5 \cdot 1 \\
4 \cdot 6 \\
4 \cdot 6 \\
4 \cdot 6 \\
4 \cdot 6\end{array}$ & $\begin{array}{l}4 \cdot 3 \\
4 \cdot 3 \\
4 \cdot 3 \\
4 \cdot 2 \\
4 \cdot 2 \\
4 \cdot 1 \\
3 \cdot 8 \\
4 \cdot 2 \\
3 \cdot 8 \\
3 \cdot 9\end{array}$ & $\begin{array}{l}5 \cdot 05 \\
4 \cdot 75 \\
4.59 \\
4 \cdot 43 \\
4 \cdot 58 \\
4 \cdot 50 \\
4 \cdot 24 \\
4 \cdot 33 \\
4 \cdot 18 \\
4 \cdot 34\end{array}$ \\
\hline $\begin{array}{r}\mathrm{T}_{3} \mathrm{R}_{1} \mathrm{C}_{1} \\
\mathrm{C}_{3} \\
\mathrm{C}_{5} \\
\mathrm{R}_{3} \mathrm{C}_{1} \\
\mathrm{C}_{3} \\
\mathrm{R}_{5} \mathrm{C}_{1}\end{array}$ & $\begin{array}{l}4 \cdot 8 \\
4 \cdot 8 \\
4 \cdot 8 \\
4 \cdot 8 \\
4 \cdot 8 \\
4 \cdot 8\end{array}$ & $\begin{array}{l}6 \cdot 0 \\
6 \cdot 1 \\
5 \cdot 8 \\
5 \cdot 8 \\
5 \cdot 9 \\
5 \cdot 9\end{array}$ & $\begin{array}{l}4 \cdot 9 \\
4 \cdot 9 \\
4 \cdot 9 \\
4^{\circ} 9 \\
4^{\circ} 9 \\
4^{\circ} 9\end{array}$ & $\begin{array}{l}5 \cdot 54 \\
5 \cdot 6 \mathrm{I} \\
5 \cdot 5 \mathrm{I} \\
5 \cdot 50 \\
5 \cdot 56 \\
5 \cdot 46\end{array}$ & $\begin{array}{l}4 \cdot 8 \\
4 \cdot 8 \\
4 \cdot 8 \\
4 \cdot 8 \\
4 \cdot 8 \\
4 \cdot 8\end{array}$ & $\begin{array}{l}6 \cdot 0 \\
6 \cdot 0 \\
5 \cdot 9 \\
6 \cdot 1 \\
6 \cdot 2 \\
6 \cdot 0\end{array}$ & $\begin{array}{l}4 \cdot 9 \\
4^{\circ} \cdot 9 \\
4 \cdot 9 \\
4 \cdot 9 \\
4 \cdot 9 \\
4 \cdot 9\end{array}$ & $\begin{array}{l}5 \cdot 5 \mathrm{I} \\
5 \cdot 62 \\
5 \cdot 59 \\
5.56 \\
5 \cdot 66 \\
5 \cdot 55\end{array}$ & $\begin{array}{l}4 \cdot 8 \\
4 \cdot 8 \\
4 \cdot 8 \\
4 \cdot 8 \\
4 \cdot 8 \\
4 \cdot 8\end{array}$ & $\begin{array}{l}4 \cdot 6 \\
4 \cdot 6 \\
4 \cdot 7 \\
4 \cdot 7 \\
4 \cdot 6 \\
4 \cdot 6\end{array}$ & $\begin{array}{l}4 \cdot 4 \\
4 \cdot 4 \\
4 \cdot I \\
4 \cdot I \\
3 \cdot 9 \\
4 \cdot 0\end{array}$ & $\begin{array}{l}4 \cdot 5^{2} \\
4 \cdot 53 \\
4 \cdot 4^{2} \\
4 \cdot 4^{2} \\
4 \cdot 31 \\
4 \cdot 4^{\circ}\end{array}$ \\
\hline $\begin{array}{r}\mathrm{T}_{5} \mathrm{R}_{1} \mathrm{C}_{1} \\
\mathrm{C}_{3} \\
\mathrm{R}_{3} \mathrm{C}_{1}\end{array}$ & $\begin{array}{l}4 \cdot 7 \\
4 \cdot 7 \\
4 \cdot 7\end{array}$ & $\begin{array}{l}5 \cdot 8 \\
5 \cdot 8 \\
5 \cdot 8\end{array}$ & $\begin{array}{l}4 \cdot 9 \\
4.7 \\
4.9\end{array}$ & $\begin{array}{l}5 \cdot 4^{2} \\
5 \cdot 4^{2} \\
5 \cdot 44\end{array}$ & $\begin{array}{l}4 \cdot 7 \\
4 \cdot 7 \\
4 \cdot 7\end{array}$ & $\begin{array}{l}5 \cdot 7 \\
5 \cdot 7 \\
5 \cdot 7\end{array}$ & $\begin{array}{l}4 \cdot 9 \\
4 \cdot 9 \\
4 \cdot 9\end{array}$ & $\begin{array}{l}5 \cdot 4^{1} \\
5^{\circ} \cdot 45 \\
5 \cdot 4^{2}\end{array}$ & $\begin{array}{l}4 \cdot 7 \\
4 \cdot 7 \\
4 \cdot 7\end{array}$ & $\begin{array}{l}4 \cdot 6 \\
4 \cdot 6 \\
4 \cdot 6\end{array}$ & $\begin{array}{l}4 \cdot 4 \\
4 \cdot 3 \\
4 \cdot 3\end{array}$ & $\begin{array}{l}4 \cdot 5^{2} \\
4 \cdot 49 \\
4 \cdot 47\end{array}$ \\
\hline $\begin{array}{c}\mathrm{T}_{7} \mathrm{R}_{1} \mathrm{C}_{1} \\
\text { Shive's } \\
\mathrm{R}_{5} \mathrm{C}_{2} \\
\text { Totting- } \\
\text { ham's } \\
\mathrm{T}_{3} \mathrm{R}_{1} \mathrm{C}_{4}\end{array}$ & $4 \cdot 7$ & $5 \cdot 7$ & $4 \cdot 9$ & $5 \cdot 3^{8}$ & $4 \cdot 7$ & $5^{\cdot 6}$ & $4^{\cdot 6}$ & $5 \cdot 36$ & $4 \cdot 7$ & $4 \cdot 6$ & $4 \cdot 4$ & $4 \cdot 55$ \\
\hline & & & & & $4^{\circ} 6$ & $5 \cdot 7$ & $4 \cdot 7$ & $5 \cdot 29$ & & & & \\
\hline
\end{tabular}

Ammonium-sulphate series $(G)$. Source of iron $\mathrm{FePO}_{4}$. $\mathrm{pH}$ values.

\section{.}


graphs show clearly the marked increase in the average $\mathrm{pH}$ values of the unmodified Tottingham solutions of series $\mathrm{E}$ and $\mathrm{F}$, and a considerable decrease in these values for all but one of the solutions containing ammonium sulphate (series G), thus indicating that the effect of the growing plants upon reaction change is directly opposite in the two types of solutions here used. The graphs of series $\mathrm{E}$ and $\mathrm{F}$ further show that the greatest reaction change occurred in the solutions with low proportions of the mono-potassium phosphate, and that the reaction change was correspondingly less as the concen-

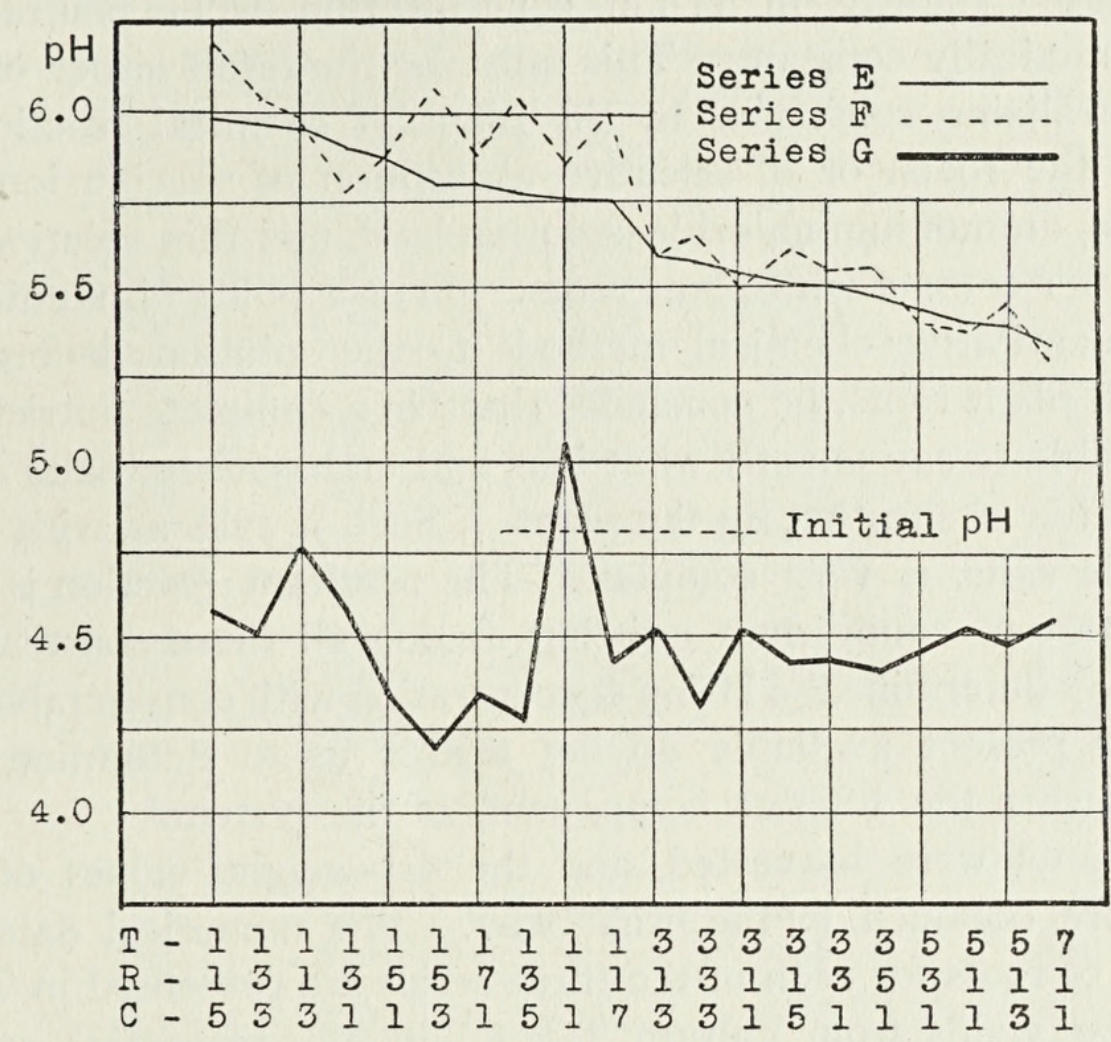

FIG. 3. Graphs of $\mathrm{pH}$ values of culture solutions after contact with plant roots during the growth intervals between solution renewals; averages of all tests made during the growth period.

tration of this salt increased. On the other hand, no such relation is shown for the solutions containing ammonium sulphate (series $G$ ).

It has been found by a number of investigators that one of the effects of plants upon a nutrient medium containing an ammonium compound is to increase the acidity of the medium. As far back as I 860 this was recognized by Knop (24) in solution cultures, and shortly afterwards was mentioned by Rautenberg and Kühn (34). Among many other workers who have confirmed this observation may be mentioned Mazé (28), Nathansohn (30), Ehrenberg (5), Prianischnikow (33), Nikitinsky (31), Jones and Shive (20), and others. Pantanelli (32) in a series of studies with single salt solutions has shown how the ratio of the anion to the kation changes as one ion is removed by the plant more rapidly than the other. In a similar way Breazeale and Le Clerc (1) showed that this differential ion absorption by plant roots occurs in solutions of potassium chloride and potassium sulphate. 
Hall, Miller, and Gimingham (12) ascribe the acidity of the acid soils of the Rothamstead grass plots that have been treated with ammonium salts to the action of various micro-fungi which are able to remove the ammonium-ion from a solution of its salts and set free the acids with which it was combined.

Hoagland (14) made some studies in changes of reaction in nutrient solutions by barley seedlings, and says: "In general it was found that alkaline solutions decreased markedly in $\mathrm{OH}$-ion concentration, acid solutions decreased slightly in $\mathrm{H}$-ion concentration, while neutral solutions remained practically constant. This must be the result either of the secretion of neutralizing substances by the plant, of chemical reaction with the material of the roots, or of selective absorption of specific ions.' Later (15) with an ammonium chloride solution he found this solution increased in acidity after contact with plant roots. On continuing his studies (16), and applying quantitative chemical methods to the solutions before and after contact with plant roots, he concludes that 'in a complete nutrient solution it is impossible to say exactly what ions and undissociated salts are present before and after absorption by the plant. Such a system, with its various hydrolysable salts, is very complex. The resultant reaction is due to the particular state of equilibrium existing among all these constituents; and while we may determine the $\mathrm{H}$-ion concentration with considerable accuracy, the data at present available do not enable us to determine the exact relations between the different components of the system.'

The plants were harvested, and the dry-weight values of tops and of roots were obtained in the usual way. The numerical data of yields of tops and of roots for each of the three series are presented in Table $\mathrm{V}$ in terms of the yields from culture $T_{1} R_{1} C_{1}$ in the respective series taken as unity, but the actual dry-weight yields of this culture are given in parentheses in grammes. The highest five yield values in each series (upper one-fourth) are indicated by bold-face type.

From the data of Table $\mathrm{V}$ it will be observed that a large range in relative yield values occurs within each series, which may be attributed in the main to the variations in the relative salt proportions from culture to culture in the respective series, but since the low and medium yields have little that might be of interest or value in this connexion they will not here be considered.

The relative yield values for the five cultures producing high yields of tops and of roots' in each series as given in Table $\mathrm{V}$ were plotted on the tetrahedral diagrams like that employed by Tottingham (37), but here presented in perspective in somewhat the same manner as was done by Espino (6).

The high yield values of series E, F, and G are represented separately on the diagrams of Figs. 4, 5, and 6 respectively, areas of tops and of roots 
of the same series being represented on a single diagram and distinguished by differences in shading. The yields of tops are represented by dotted areas, and those of roots by stippled areas.

\section{TABLE V.}

Relative dry-weight yields of soy bean tops and roots from the Tottingham solutions of series $E$ and $F$ and from the modified Tottingham solutions of series $G$, supplied with suitable forms of iron and in sufficient amounts to prevent chlorosis.

\begin{tabular}{|c|c|c|c|c|c|c|}
\hline \multirow{2}{*}{$\begin{array}{l}\text { Culture } \\
\text { number. }\end{array}$} & \multicolumn{2}{|c|}{$\begin{array}{l}\text { Series } E \text {, } \\
\text { source of iron } \mathrm{FePO}_{4} \text {. }\end{array}$} & \multicolumn{2}{|c|}{$\begin{array}{l}\text { Series } F, \\
\text { source of iron } \mathrm{FeSO}_{4} \text {. }\end{array}$} & \multicolumn{2}{|c|}{$\begin{array}{l}\text { Series } G, \\
\text { source of iron } \mathrm{FePO}_{4} \text {. }\end{array}$} \\
\hline & Tops. & Roots. & Tops. & Roots. & Tops. & Roots. \\
\hline $\mathrm{T}_{1} \mathrm{R}_{1} \mathrm{C}_{1}$ & $\begin{array}{l}I \cdot 00 \\
\left(3 \cdot 19^{I}\right.\end{array}$ & $\begin{array}{l}I \cdot 00 \\
\left(0 \cdot 45^{6} \mathrm{I}\right)\end{array}$ & $\begin{array}{l}\mathrm{I} \cdot 00 \\
(3 \cdot 543 \mathrm{I})\end{array}$ & $\begin{array}{l}\mathbf{I} \cdot 00 \\
(0.5891)\end{array}$ & $\begin{array}{l}\text { I.00 } \\
(5 \cdot 1786)\end{array}$ & $\begin{array}{l}\mathbf{r} \cdot \mathbf{0 0} \\
(0.9828)\end{array}$ \\
\hline $\mathrm{C}_{3}$ & $I \cdot 39$ & $I \cdot 23$ & $I \cdot 30$ & 0.96 & 0.87 & \\
\hline & $I \cdot 5^{2}$ & $\mathrm{I} \cdot 33$ & $\mathrm{I} \cdot 47$ & 0.99 & 0.93 & $0.5 \mathrm{I}$ \\
\hline $\mathrm{R}_{3} \mathrm{C}_{7}$ & $\begin{array}{l}0.73 \\
0.06\end{array}$ & 0.65 & $\mathrm{I} \cdot 07$ & 0.45 & 0.59 & 0.20 \\
\hline${ }_{\mathrm{C}_{3}}^{\mathrm{K}_{3} \mathrm{C}_{1}}$ & $\begin{array}{l}0.96 \\
\text { I.59 }\end{array}$ & $\begin{array}{l}0.98 \\
\mathrm{I} \cdot 32\end{array}$ & $\begin{array}{l}1 \cdot 108 \\
0.10\end{array}$ & $\begin{array}{l}0.69 \\
0.8 I\end{array}$ & $\begin{array}{l}0.59 \\
0.70\end{array}$ & $\begin{array}{l}0.40 \\
0.2=\end{array}$ \\
\hline $\mathrm{C}_{5}^{\circ}$ & 0.94 & 0.76 & $\mathrm{I} \cdot 22$ & 0.53 & 0.65 & $\begin{array}{l}0.35 \\
0.23\end{array}$ \\
\hline $\begin{aligned} \mathrm{R}_{5} \mathrm{C}_{1} \\
\mathrm{C}_{3}\end{aligned}$ & 0.88 & 0.86 & 0.87 & 0.67 & 0.50 & 0.30 \\
\hline $\begin{array}{r}\mathrm{C}_{3} \\
\mathrm{R}_{7} \mathrm{C}_{1}\end{array}$ & $0.9 \mathrm{I}$ & $0.7 \mathrm{I}$ & 0.97 & $0.5^{\circ}$ & $0.5^{\circ}$ & $0 \cdot 18$ \\
\hline $\mathrm{R}_{7} \mathrm{C}_{1}$ & 0.65 & 0.46 & 0.65 & $0.5^{2}$ & 0.33 & 0.37 \\
\hline $\begin{array}{r}\mathrm{T}_{3} \mathrm{R}_{1} \mathrm{C}_{1} \\
\mathrm{C}_{3}\end{array}$ & $\mathrm{I} \cdot \mathrm{I} 5$ & 0.94 & 0.93 & $0.7^{6}$ & 0.67 & 0.49 \\
\hline $\begin{array}{l}\mathrm{C}_{3} \\
\mathrm{C}_{5}\end{array}$ & $\mathrm{I} \cdot 48$ & $\mathrm{I} \cdot 37$ & $\mathrm{I} \cdot 38$ & $\mathbf{I} \cdot 28$ & 0.91 & \\
\hline $\mathrm{R}_{3} \mathrm{C}_{1}$ & $\begin{array}{l}0.97 \\
0.93\end{array}$ & $\begin{array}{l}0.64 \\
0.80\end{array}$ & $\begin{array}{l}\text { I.2I } \\
0.00\end{array}$ & 0.58 & 0.75 & $\begin{array}{l}0 \cdot 3 I \\
0 \cdot 4^{2}\end{array}$ \\
\hline $\mathrm{C}_{3}$ & 0.86 & 0.64 & 0.98 & 0.47 & 0.66 & 0.23 \\
\hline $\mathrm{R}_{5} \mathrm{C}_{1}$ & 0.68 & 0.56 & 0.76 & $0.5^{8}$ & 0.44 & 0.25 \\
\hline $\mathrm{T}_{5} \mathrm{R}_{1} \mathrm{C}_{1}$ & $I \cdot 09$ & $1 \cdot 09$ & 0.84 & $0 \cdot 6_{5}$ & 0.52 & $0.4^{2}$ \\
\hline $\begin{array}{r}\mathrm{C}_{3} \\
\mathrm{R}_{3} \mathrm{C}_{1}\end{array}$ & I. I7 & 0.99 & 0.96 & $0.5 \mathrm{I}$ & 0.68 & 0.26 \\
\hline $\mathrm{K}_{3} \mathrm{C}_{1}$ & $\mathrm{I} \cdot 03$ & $0.9^{2}$ & 0.73 & $0.5^{8}$ & 0.45 & 0.29 \\
\hline $\begin{array}{l}\mathrm{T}_{7} \mathrm{R}_{1} \mathrm{C}_{1} \\
\text { Shive's }\end{array}$ & $I \cdot 02$ & 0.95 & $0.8 \mathrm{I}$ & 0.65 & 0.47 & $0 \cdot 34$ \\
\hline $\begin{array}{l}\mathrm{R}_{5} \mathrm{C}_{2} \\
\text { ottingham' }\end{array}$ & & & $I \cdot 40$ & $\mathrm{I} \cdot 07$ & & \\
\hline $\mathrm{T}_{3} \mathrm{R}_{1} \mathrm{C}_{4}$ & & & $I \cdot 28$ & $I \cdot 26$ & & \\
\hline
\end{tabular}

Examination of the three diagrams graphically representing the high yields from the three series here considered shows that there is much overlapping of the areas of top yields and root yields in each of the three series. In some instances, as in series E, Fig. 4, the areas are practically superimposed. This indicates a very close agreement between tops and roots with respect to the proportions of the salts required to produce high yields.

Comparing the diagrams of Figs. 4 and 5 (series $\mathrm{E}$ and F) it will be observed that the areas representing high yields of tops and roots occupy the same general regions at the bases of the several triangles on each diagram. This is to be expected, of course, since the two series are alike in every respect except in the amounts and forms of iron supplied to the cultures, ferric phosphate being the source of iron for the plants of series $\mathrm{E}$ and ferrous sulphate for those of series $\mathrm{F}$, in such amounts as were 


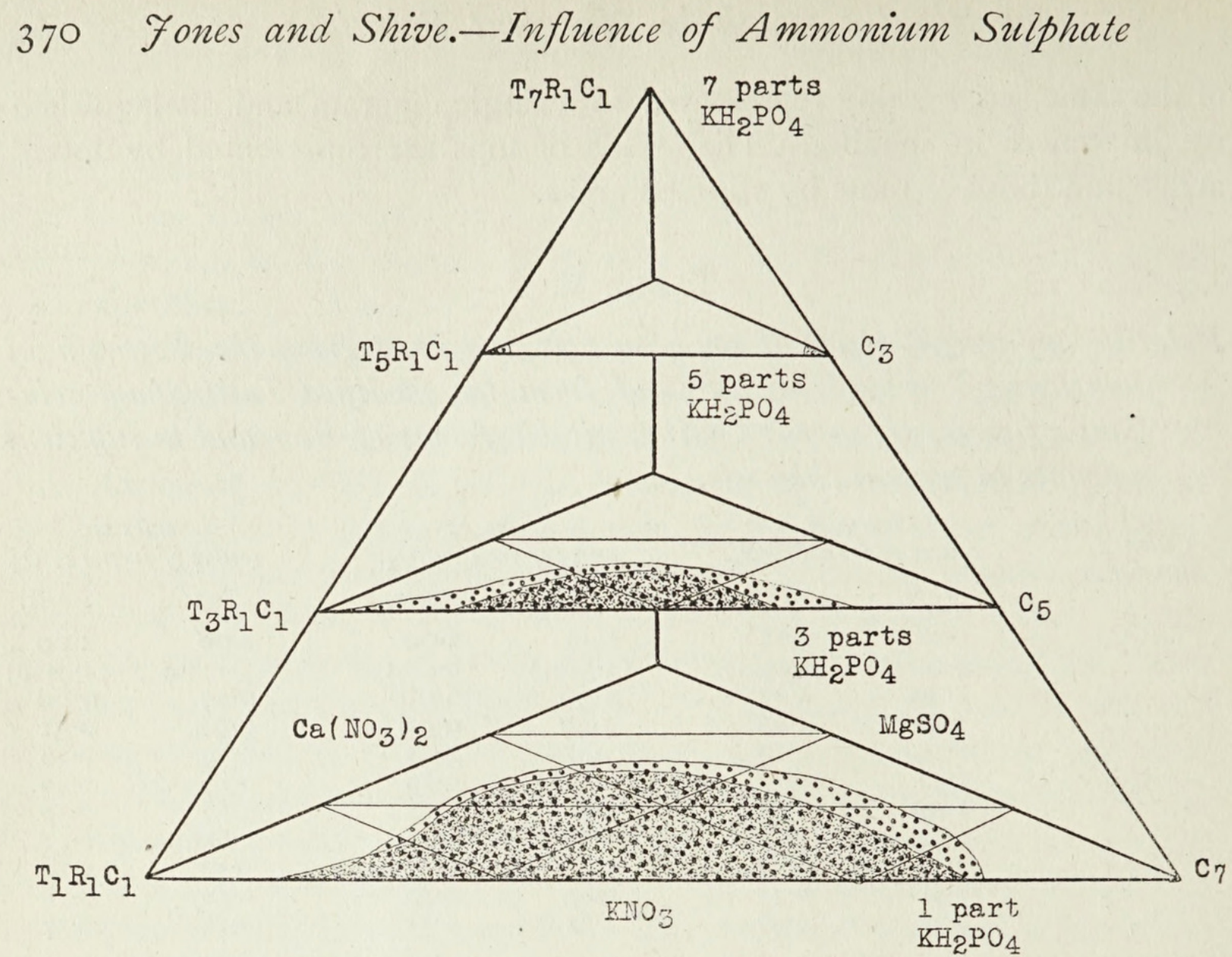

FIG. 4. Distribution of the highest five yields of soy bean tops and roots from the cultures of series E, supplied with ferric phosphate as the source of iron for the plants. Yields of tops represented by dotted areas, those of roots by stippled areas.

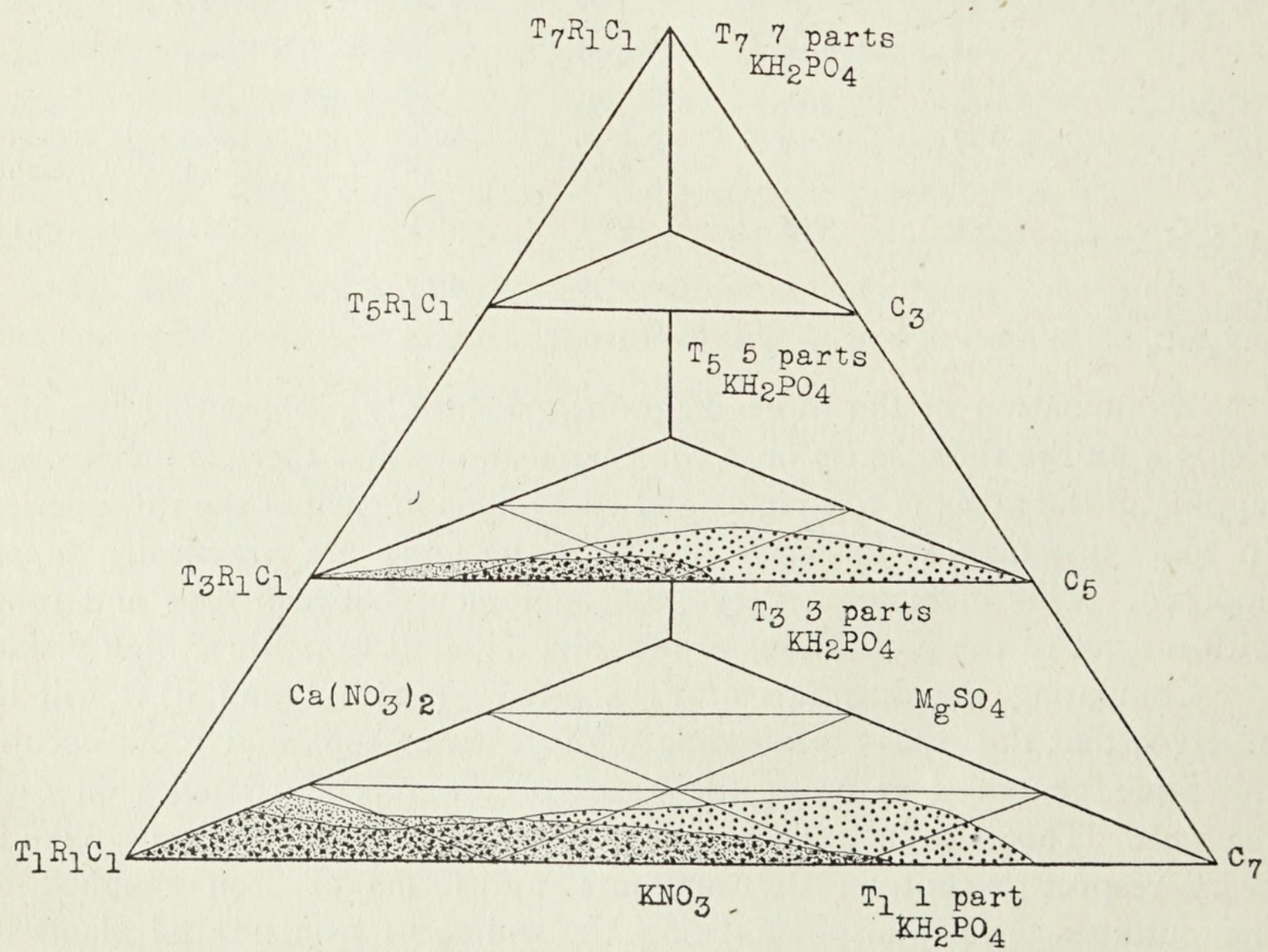

FIG. 5. Distribution of the highest five yields of soy bean tops and roots from the cultures of series F, supplied with ferrous sulphate as the source of iron for the plants. Yields of tops represented by dotted areas, those of roots by stippled areas. 
previously found to be very efficient in maintaining the plants in a healthy condition without chlorosis in these solutions. Three cultures of the five in each of these two series producing high yields of tops and three producing high yields of roots are corresponding cultures, and are included in the areas marking high yields in both series. The maximum yield of tops was produced by culture $T_{1} R_{3} C_{3}$ in series $E$ and by culture $T_{1} R_{1} C_{5}$ in series $F$. The maximum yield of roots in each of the two series was produced by culture $\mathrm{T}_{3} \mathrm{R}_{1} \mathrm{C}_{3}$.

A comparison of the diagrams of Fig. 6 (series G, modified Tottingham

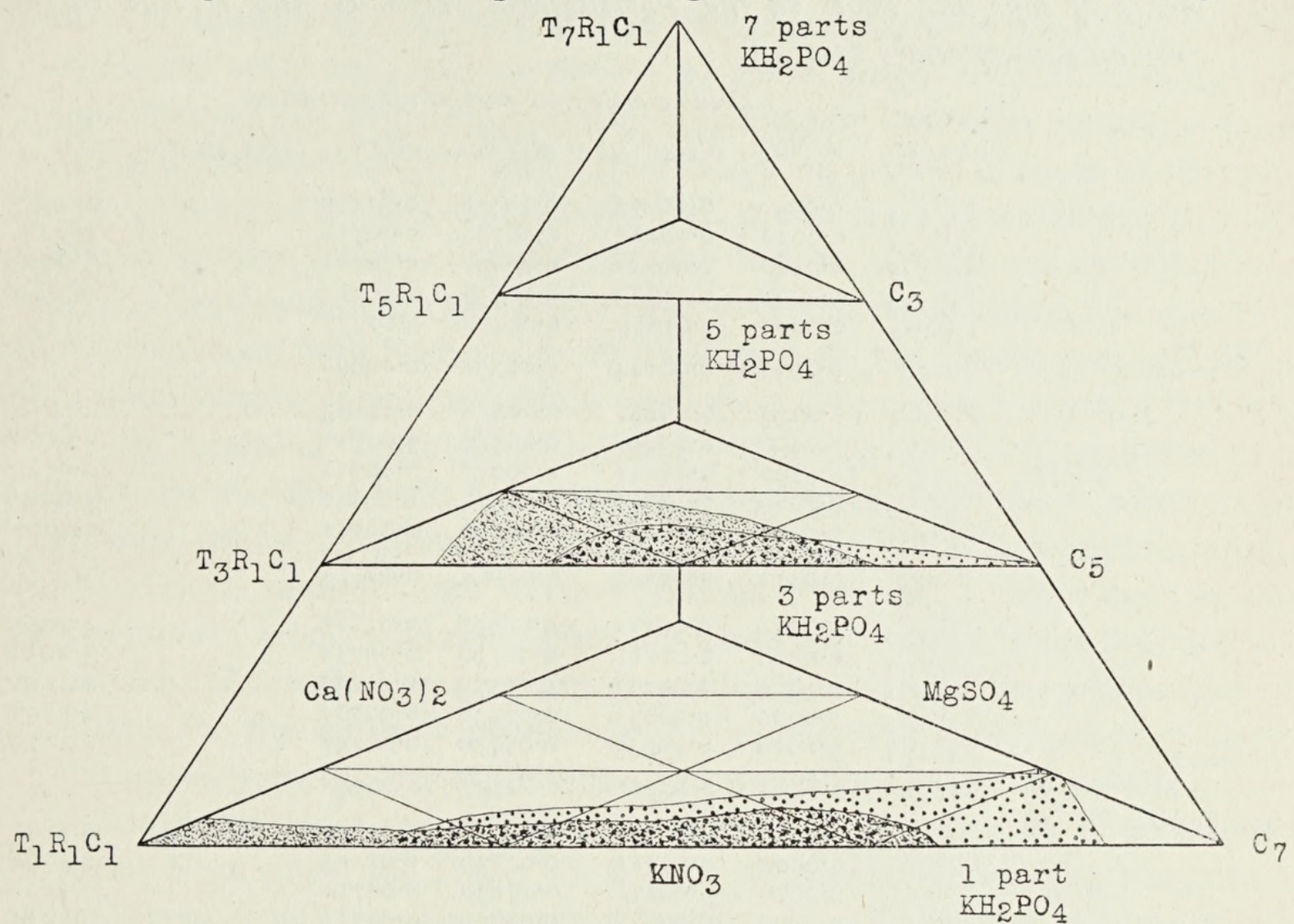

FIG. 6. Distribution of the highest five yields of soy bean tops and roots from the cultures of series G, supplied with ferric phosphate as the source of iron for the plants. Yields of tops represented by dotted areas, those of roots by stippled areas.

solutions) with those of Figs. 4 and 5 shows the areas of high yields of both tops and roots on all three diagrams to occupy the same general positions at the bases of the several triangles. Three of the five cultures which produced high yields of tops and three of those which gave high root yields in each series are corresponding cultures, and are included in the yield areas on each of the three diagrams. The maximum yield of both tops and roots from the cultures containing ammonium sulphate (series G, Fig. 6) was produced by culture $T_{1} R_{1} C_{1}$.

The volume-molecular partial concentrations of the salts, and the ranges of these for the culture solutions which produced the highest five yields of tops and roots in each series, are given in Table VI, together with the absolute dry-weight yields produced. The maximum yields from each 
series are indicated by bold-face type. The data given in this table refer to the cultures comprised in the yield areas on the diagrams of Figs. 4, 5, and 6 . At the bottom of the table are given the maximum and minimum partial concentrations employed with each salt, and the total ranges of these for the entire series.

TABLE VI.

Absolute dry-weight yields: volume-molecular partial concentrations and ranges of these for the salts in the solutions producing the highest five yields of tops and roots in the Tottingham series $E$ and $F$, and in the ammonium-sulphate series $G$.

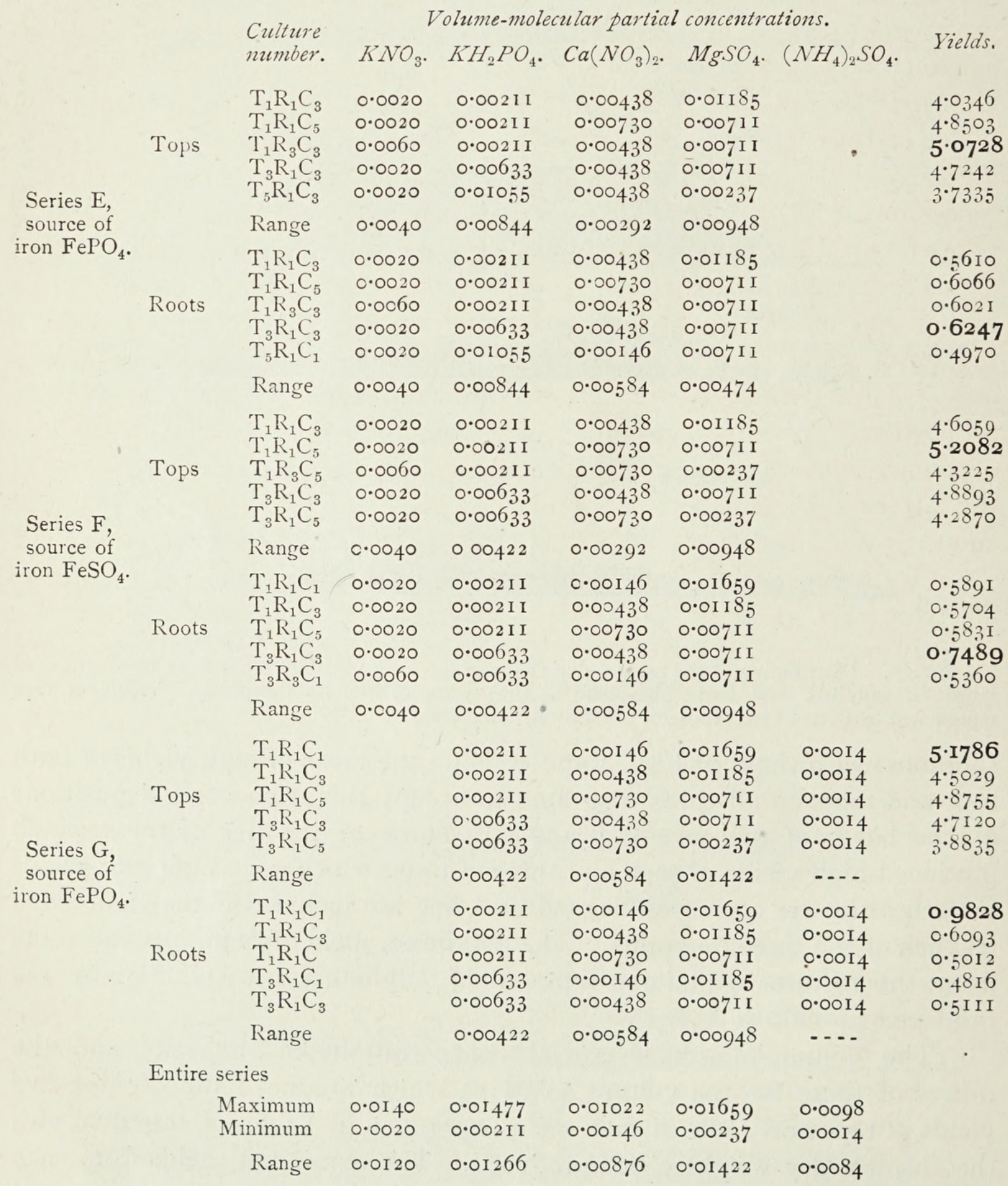


From the data of Table VI and from the distribution of the areas representing high yields on the diagrams of Figs. 4, 5, and 6 it is at once apparent that good growth of soy bean tops in the Tottingham series $\mathrm{E}$ and $\mathrm{F}$ is correlated with only narrow ranges in the proportions of potassium nitrate and calcium nitrate, but with relatively wide ranges in the proportions of the other two salts. For the cultures producing the highest five yields of roots in the two series, relatively wide ranges are shown in the proportions of all the salts except potassium nitrate. However, the ranges in the salt proportions correlated with high yields of both tops and roots are always less extensive than the corresponding total ranges employed, and with only one exception do these ranges include the highest proportions of any salt used, this exception being indicated for magnesium sulphate in culture $T_{1} R_{1} C_{1}$, which produced a high yield of roots in series $F$. On the other hand, the ranges in the salt proportions associated with high yields of tops in these series include the lowest proportions of potassium nitrate, mono-potassium phosphate, and magnesium sulphate, and likewise those correlated with high yields of roots include the lowest proportions of potassium nitrate, mono-potassium phosphate, and calcium nitrate.

The modified Tottingham solutions of series $G$ which produced the highest five yields of both tops and roots are limited to those solutions of the series which comprise the lowest proportions of ammonium sulphate only. These solutions are further characterized by a low range in the proportions of mono-potassium phosphate and high ranges in the proportions of calcium nitrate and magnesium sulphate, the range in the proportions of the latter for the cultures producing the highest five yields of tops being co-extensive with the corresponding total range for the entire series.

Comparing now the absolute dry-weight yields of series $\mathrm{E}$ with those of series $\mathrm{F}$ as given in Table VI, it will be observed that the maximum yield of tops from the series in which iron was supplied to the cultures in the form of ferrous sulphate (series F) is slightly superior to the corresponding yield from series $\mathrm{E}$, in which the source of iron was ferric phosphate. The difference in these values, however, is scarcely large enough to be significant, although the average of the highest five yields from series $F$ shows a pronounced superiority over the corresponding average from series E. The average of the highest five yields of roots, as well as the maximum yield from series $\mathrm{F}$, show a marked superiority over the corresponding yield from series E. It thus appears that ferrous sulphate when supplied in the proper concentrations is a better source of iron for soy bean plants grown in the Tottingham solutions than is ferric phosphate under similar conditions.

The maximum yield and the average of the highest five yields of tops from series $G$ are approximately the same in value as the corresponding yields from series $F$ and slightly superior to those from series $E$, but the maximum and average yields of roots from series $G$ are much superior 
to those from the other two series. On the whole, it appears that the modified Tottingham solutions of series $G$, in which nitrogen is available for the plants in the forms of both nitrate and ammonium, are somewhat more efficient than are the unmodified Tottingham solutions for the growth of soy bean plants during the early phases of development, but any of the solutions whose formulae appear in Table VI may be expected to produce good growth of this species if supplied with a suitable form of iron in the proper concentrations.

\section{SuMMARY.}

The experiments described in this paper were conducted for the purpose of studying, in a comparative way, the effects of ammonium sulphate upon the growth of soy beans in nutrient solutions during the early stages of development, and to determine the influence of this salt upon the availability for the plants of different forms of iron. A study was made also of the reaction change of the nutrient solutions induced by contact with plant roots. Two type-series of culture solutions were used. The first of these comprised twenty solutions selected from the Tottingham series of eightyfour, and the second consisted of the same solutions modified by substituting ammonium sulphate for the potassium nitrate in equivalent osmotic concentrations. All the solutions had a total osmotic concentration value of approximately one atmosphere. Ferric phosphate in an aqueous suspension and ferrous sulphate in solution form were added in stated amounts of iron per litre of nutrient solution. The culture solutions were renewed at regular intervals of three and one-half days throughout the growth period of approximately five weeks.

The main results of the experiments may be summarized as follows :

I. The plants grown in the Tottingham solutions invariably produced a marked decrease in the hydrogen-ion concentration of the solutions.

2. The plants grown in the solutions containing ammonium sulphate invariably increased the hydrogen-ion concentration of these solutions during the early stages of growth, the hydrogen-ion concentrations of these solutions being maintained at a much higher level than those of the unmodified Tottingham solutions, although the initial $\mathrm{pH}$ values of corresponding solutions of the two types were practically the same.

3. The nature of the salt constituents determines the direction of the reaction change of the culture solutions in contact with the roots of the growing soy bean plants.

4. Ferric phosphate in quantities of less than one milligram of iron per litre of nutrient solution was not sufficiently available in the Tottingham solutions to supply the needs of the plants for iron during the early stages 
of growth. On the other hand, this form of iron in quantities of less than one-half milligram of iron per litre of solution was ample to supply the needs of the plants for this element in the solutions containing ammonium sulphate. The maintenance by the plants of a higher level in the hydrogenion concentration of the solutions containing ammonium sulphate, and the possible influence of this salt upon the permeability of the plant cells towards iron, undoubtedly account for the greater efficiency of iron in these solutions.

5. Ferrous sulphate in quantities of from 0.25 to 0.50 milligram of iron per litre of nutrient solution was sufficiently available in the Tottingham solutions to satisfy the needs of the plants for iron. However, ferrous sulphate in the solution containing ammonium sulphate produces a condition very toxic to the plants, the degree of toxicity increasing with increase in the amounts of iron from 0.25 to 5.00 milligrams per litre of nutrient solution.

6. Ferrous sulphate when used in too high concentrations produces on the leaves of soy bean plants in both series a characteristic brown specking which is more pronounced in the solutions containing ammonium sulphate than in the unmodified Tottingham solutions.

7. The availability for the plants of a given iron compound and its efficiency appear to be determined in large measure by the composition of the nutrient solution and by the nature of the reaction change induced by contact with the plant roots.

8. With the solutions containing the salts $\mathrm{KNO}_{3}, \mathrm{KH}_{2} \mathrm{PO}_{4}, \mathrm{Ca}\left(\mathrm{NO}_{3}\right)_{2}$, and $\mathrm{MgSO}_{4}$ (Tottingham solutions) the maximum yield of soy bean tops was obtained when these salts were present in the volume-molecular proportions $0.0020,0.00211,0.00730$, and 0.007 II, respectively, with ferrous sulphate as the source of iron. The maximum yield of roots was obtained with a solution containing these salts in the volume-molecular proportions $0.0020,0.00633,0.00438$, and 0.007 II, respectively, with ferrous sulphate as the source of iron. Good yields of tops and roots were obtained with only a narrow range in the proportions of potassium nitrate, but with relatively wide ranges in the proportions of the other salts.

9. With the solutions containing $\left(\mathrm{NH}_{4}\right)_{2} \mathrm{SO}_{4}, \mathrm{KH}_{2} \mathrm{PO}_{4}, \mathrm{Ca}\left(\mathrm{NO}_{3}\right)_{2}$, and $\mathrm{MgSO}_{4}$ the maximum yield of both tops and roots was obtained when these salts were present in the volume-molecular proportions $0.0014,0.002 \mathrm{II}$, 0.00146 , and 0.01659 , respectively, with ferric phosphate as the source of iron. Good yields of tops and roots were obtained with only the lowest proportions of ammonium sulphate but with relatively wide ranges in the proportions of the other salts.

Io. In general, high yields of tops were associated with high yields of roots. 


\section{LITERATURE CITED.}

1. Brenzeale, J. F., and Le Clerc, J. A. (1912): The Growth of Wheat Seedlings as affected by Acid or Alkaline Conditions. U.S. Dept. Agr. Bur. Chem. Bull. I49.

2. Clark, W. M., and Lubs, H. A. (1917): The Colorimetric Determination of Hydrogen-ion Concentration and its Applications in Bacteriology. Journ. Bact., vol. ii, No. I, pp. I-34 ; No. 2, pp. 109-36; No. 3 , pp. 191-236.

3. Corson, G. E., and Bakke, A. L。(1917): The Use of Iron in Nutrient Solutions for Plants. Proc. Iowa Acad. Sci., vol. xxiv, pp. 477-82.

4. Daikuhara, G. (1905): On the Application of Magnesia in the Form of Magnesium Sulphate for the Needs of the Rice Plant. Bull. of the Imp. Cent. Agr. Exp. Sta. (Japan), vol. i, pp. $23-9$.

5. Ehrenberg, P. (1908): Beiträge zur Ammoniakfrage. Landw. Vers.-Stat., vol. lxix, pp. ${ }^{2} 59-94$.

6. Espino, R. B. (1920): Some Aspects of the Salt Requirements of Young Rice Plants. Philippine Journ. of Sci., vol. xvi, pp. $455^{-525}$.

7. Free, E. E. (1915) : A Relative Score Method of recording Comparisons of Plant Conditions and other Unmeasured Characters. Plant World, vol. xviii, p. 249-5

8. Gile, P. L., and Carrero, J. O. (1916): Assimilation of Iron by Rice from certain Nutrient Solutions. Journ. Agr. Research, vol. vii, pp. 5०3-28.

9. $(1920)$ : Cause of Lime-induced Chlorosis and Availability of Iron in the Soil. Ibid., vol. xx, pp. 33-62.

10. Gillespie, L. J. (1920): Colorimetric Determination of Hydrogen-ion Concentration without Buffer Mixtures, with especial Reference to Soils. Soil Sci., vol. ix, pp. I I 5-36.

11. GRIS, E. (1844): Nouvelles expériences sur l'action des composés ferrugineux solubles, appliquées à la végétation, et spécialement au traitement de la chlorose et de la débilité des plants. Compt. Rend. Acad. Sci. (Paris), vol. xix, pp. III8-I9.

12. Hall, A. D., Miller, N. H. J., and Gimingham, C. T. (1908): Nitrification in Acid Soils. Proc. Roy. Soc. London, Series B., vol. lxxx, pp. I96-2I 2.

13. Hartwell, B. L., and Pember, F. R. (1908): The Relative Toxicity of Ferrous Sulphate to Barley and Rye Seedlings. R. I. Agr. Exp. Sta., 2 Ist Ann. Rep., I 907-8, pp. 286-94.

14. Hoagland, D. R. (1917): The Effect of Hydrogen and Hydroxyl Ion Concentration on the Growth of Barley Seedlings. Soil Sci., vol. iii, pp. 547-60.

15. (1918): The Relation of the Plant to the Nutrient Solution. Science, N.S., vol. xlviii, No. I 243 , pp. $4^{22-5}$.

16. (1919): Relation of the Concentration and Reaction of the Nutrient Medium to the Growth and Absorption of the Plant. Journ. Agr. Research, vol. xviii, pp. 73-II 7 .

17. Hutchinson, H. B., and Miller, N. H. J. (1908): Direct Assimilation of Ammonium Salts by Plants. Journ. Agr. Sci., vol. iii, pp. I 79-94.

18.

(1911): The Direct Assimilation of Inorganic and Organic Forms of Nitrogen by Higher Plants. Centralbl. Bakt., Abt. ii, vol. xxx, pp. $5^{\mathrm{I}} 3-47$.

19. Jones, L. H., and Shive, J. W. (1921): The Influence of Iron in Forms of Ferric Phosphate and Ferrous Sulphate upon the Growth of Wheat in a Nutrient Solution. Soil Sci., vol.xi, pp. 93-9.

20 .

(1921): Effect of Ammonium Sulphate upon Plants in Nutrient Solutions supplied with Ferric Phosphate and Ferrous Sulphate as Sources of Iron. Journ. Agr. Research, vol. xxi, pp. 70I-28.

21. Kelley, W. P. (1911): The Assimilation of Nitrogen by Rice. Hawaii Agr. Exp. Sta. Bull. ${ }_{24}$, U.S.D.A., Washington, D.C.

22. $(1914)$ Rice Soils of Hawaii ; their Fertilization and Management. Ibid., 3I.

23. Kellner, O. (1884): Agriculturchemische Studien über die Reiscultur. Landw. Vers.-Stat., vol. $x x x$, pp. 18-34.

24. KNOP, W. (1860) : Ueber die Ernährung der Pflanzen durch wässrige Lösungen bei Ausschluss des Bodens. Ibid., vol. ii, pp. 65-99. 
25. Krauss, F. G. (1907): Rice Investigations. Hawaii Agr. Exp. Sta. Ann. Rept., pp. 67-70.

26. - (1908): Field Crop Experiments. Ibid., pp. $6_{5}-84$.

27. Lehmann, J. (1875): Ueber die zur Ernährung der Pflanzen geeignetste Form des Stickstoffes. Biedermann's Centralbl. Agr.-Chem., vol. vii, pp. 403-9.

28. MAzÉ, P. (1900): Recherches sur l'influence de l'azote nitrique et de l'azote ammoniacal sur le développement du mais. Ann. de l'Inst. Pasteur, vol. xiv, pp. 26-45.

29. Nagaoka, M. (1904-5): On the Behaviour of the Rice Plant to Nitrates and Ammonium Salts. Bull. Coll. of Agr., Tokyo Imp. Univ. (Japan), vol. vi, pp. 284-334.

30. Nathansohn, A. (1904): Weitere Mitteilungen über die Regulation der Stoffaufnahme. Jahrb. f. wiss. Bot., vol. xl, pp. 403-42.

31. Nikitinsky, J. (1904): Über die Beeinflussung der Entwicklung einiger Schimmelpilze durch Stoffwechselprodukte. Ibid., pp. I-93.

32. Pantanelli, E. (1915) : Über Ionenaufnahme. Ibid,, vol. 1vi, pp. 689-733.

33. Prianischnikow, D. (1911) : U̇ber den Einfluss von kohlensaurem Kalk auf die Wirkung von verschiedenen Phosphaten. Landw. Vers.-Stat., vol. lxxv, pp. 357-76.

34. Rautenberg, F., and KüHn, G. (1864): Vegetationsversuche im Sommer. Ibid., vol. vi, pp. $355^{-9}$.

35. Ruprecht, R. W. (1915): Toxic Effect of Iron and Aluminum Salts on Clover Seedlings. Mass. Agr. Exp. Sta. Bull. I6 I, pp I 25-9.

36. Shive, J. W. (1915): A Study of Physiological Balance in Nutrient Media. Physiol. Researches, vol. i, pp. 327-97.

37. Totringham, W. E. (1914): A Quantitative Chemical and Physiological Study of Nutrient Solutions for Plant Cultures. Ibid., pp. I $33-245$.

38. the Growth of Wheat. Plant World, vol. xix, pp. 359-70.

39. Trelease, S. F. (1920): The Growth of Rice as related to Proportions of Fertilizer Salts added to Soil Cultures. Philippine Journ. of Sci., vol. xvi, pp. 603-27.

40. , and Paulino, P. (1920): The Effect on the Growth of Rice of the Addition of Ammonium and Nitrate Salts to Soil Cultures. Philippine Agriculturist, vol. viii, pp. $293-3^{\mathrm{I}} 3$.

41. and Jurado, M. C. (1920): The Growth of Rice as related to Concentrations and Proportions of Fertilizer Salts added to Soil Cultures. Ibid., vol. ix, pp. 67-86.

42. Van Alstine, E. (1920); The Determination of Hydrogen-ion Concentration by the Colorimetric Method and an Apparatus for Rapid and Accurate Work. Soil Sci., vol. x, pp. $467-77$.

43. WolkofF, M. L. (1918) : Effect of Ammonium Sulphate in Nutrient Solutions on the Growth of Soy Beans in Sand Cultures. Ibid., vol. v, pp. 123-50. 


\section{$2 \mathrm{BHL}$ Biodiversity Heritage Library}

Jones, Linus H and Shive, John W . 1923. "Influence of ammonium sulphate on plant growth in nutrient solutions and its effect on hydrogen-ion concentration and iron availability." Annals of botany 37, 355-377. https://doi.org/10.1093/oxfordjournals.aob.a089854.

View This Item Online: https://www.biodiversitylibrary.org/item/270686

DOI: https://doi.org/10.1093/oxfordjournals.aob.a089854

Permalink: https://www.biodiversitylibrary.org/partpdf/319091

\section{Holding Institution}

New York Botanical Garden, LuEsther T. Mertz Library

\section{Sponsored by}

BHL-SIL-FEDLINK

\section{Copyright \& Reuse}

Copyright Status: Public domain. The BHL considers that this work is no longer under copyright protection.

This document was created from content at the Biodiversity Heritage Library, the world's largest open access digital library for biodiversity literature and archives. Visit BHL at https://www.biodiversitylibrary.org. 